\title{
THE TECHNOLOGY OF DEVELOPING HARMONIC HEARING
}

\author{
Galina Zavadska \\ Daugavpils Universitāte
}

\begin{abstract}
In Latvia, the development of harmonic hearing takes an important place in the process of training pre-service music teachers, because a music teacher is a conductor of a school choir or a conductor of some other choir collective. The issues relating to the system of properties of harmonic musical hearing have been highlighted in a range of scientific works by different authors (Teplov, 1947; Sloboda, 1988; Petrushin, 1997). However, at present the understanding of the nature and ways of developing harmonic hearing is sometimes quite controversial. This, first of all, can be attributed to the complexity of the interrelations between harmonic hearing and general psychic processes: perception, presentation, reproduction, memory, and thinking. The interconnectedness of general human and specific, individual qualities makes this problem difficult to study.

The solution of the problem is made difficult by the fact that a collective teaching at sol-fa classes in a higher education establishment often conflicts with learners' individual peculiarities and problems of developing their harmonic hearing. Within the frame of the case study the technology of developing harmonic hearing based on the strategy of experiential learning (model by David Kolb, 1984) has been worked out. The presented technology is grounded on individual students' learning styles and on the author's model of developing harmonic hearing (Zavadska, 2012b).
\end{abstract}

Key words: technology, case-study, harmonic hearing, educational process.

\section{Introduction}

The changes in social, scientific and political spheres in the 21 st century provide the impulse to seek for innovations in all spheres of human activity, including education. Essential changes are taking place in the contemporary musicpedagogical theory and practice of higher education institutions: the content of music education is changing, new forms of training music teachers are emerging and the technical provision of the educational process is improving.

The problem of using the case-study method in practice of professional higher education of today is quite topical (Yin, 1984/1994; Soy, 1997; Stake, 1995). This results from the general orientation of education towards providing specific professional skills, as well as orientation towards developing musical abilities of students, harmonic hearing among them.

The effectiveness of musical activity depends, firstly, on the development of musical hearing (Petrushin, 1997; Kazkayasi, Yetiser \& Ozcelik, 2006). Harmonic hearing is one of the components of musical hearing (Teplov, 1947). A consecutive and purposeful development of harmonic hearing is an integral part of polyphonic choral singing. The quality of intoning in a choir or in a vocal ensemble depends on the level of the development of harmonic hearing (Zavadska, 2012a). In Latvia, the development of harmonic hearing takes an important place in the process of training pre-service music teachers, because a music teacher is a conductor of a school choir or a conductor of some other choir collective. The issues relating to the system of properties of harmonic musical hearing have been highlighted in a range of scientific works by different 
authors (Teplov, 1947; Sloboda, 1988; Petrushin, 1997). However, at present the understanding of the nature and ways of developing harmonic hearing is sometimes quite controversial. This, first of all, can be attributed to the complexity of the interrelations between harmonic hearing and general psychic processes: perception, presentation, reproduction, memory, and thinking. The interconnectedness of general human and specific, individual qualities makes this problem difficult to study.

To solve this problem is difficult due to the fact that a collective training at solfa classes in higher education institutions often conflicts with students' individual peculiarities and problems of developing harmonic hearing of separate students. Therefore, the development of the technology of conducting classes oriented towards the development of harmonic hearing is topical for coping with practical tasks of training, teaching and educating teachers of music. Research aim: within the frame of a case-study and on the basis of the strategy of experiential learning (Kolb, 1984), to develop the technology for the development of pre-service music teachers' harmonic hearing.

\section{Theoretical background of the research}

Music education in a higher education establishment belongs to the category of professional education. Today, a music teacher has to acquire professional knowledge, skills and abilities in order to be successful in practical work at school.

A well-known American psychologist, C. Rogers (Rogers, 1969), has formulated human psychological peculiarities which can act as prerequisites for successful education:

- people have a great natural potential for learning;

- education is effective if the subject matter is topical for a person and when nothing threatens to the self of the learner;

- in the educational process the whole personality is involved, therefore it results in changes in self-organization and self-education;

- educational goals are achieved mainly if actions are directed towards maintaining openness to experience;

- self-criticism and self-evaluation enhance creativity, independence and selfconfidence.

The effectiveness of any educational process depends on its technology. As we know, technology in a broad sense is understood as knowledge of tools for implementing the processes during which qualitative changes of the object occur. Therefore, independent of the scientific context, pedagogical technologies enhance development, broaden opportunities, and improve the quality of learners' education. According to M. Klarin (Klarin, 1989), a pedagogical technology is putting systematically and consistently a previously projected pedagogical process into practice. M. Klarin interprets a pedagogical technology 
as a systemic totality and the order of functioning of all personal, instrumental and methodological tools employed for achieving pedagogical aims.

The theoretical bases of the development of harmonic hearing have been discussed in the articles written before (Zavadska, 2011a; Zavadska, 2011b; Zavadska, 2012a). The developed technology for the development of harmonic hearing is grounded on the strategy of experiential learning (Kolb, 1984), it relies on students' individual styles of learning and on the author's model for developing harmonic hearing (Zavadska, 2012b).

David Kolb's Experiential Learning Model (Kolb, 1984) of four-stage cycle of learning has gained popularity in adult learners' education to which, undoubtedly, university students belong.

David Kolb's model reflects stage-by-stage formation of adults' mental actions. Kolb's cycle is a four-stage cycle developed empirically and shows how a person learns. A. Kolb's theory is based on the principle that "immediate and concrete experiences" provide the basis for "observations and reflections". These "observations and reflections" are transformed into "abstract concepts" producing new implications for actions which can be "actively tested", in turn creating new experiences. And so on round the circle.

The cycle can be described in the following way:

1. Concrete experience;

2. Reflective observation;

3. Abstract Conceptualization;

4. Active Experimentation.

As the author sees it, learning consists of recurring stages: doing and thinking. This implies that it is not possible to learn something effectively simply by reading about this subject, by studying theory and listening to lectures. Learning cannot be effective, if new actions are performed thoughtlessly, without any analysis, reflection and summing everything up.

English psychologists P. Honey and A. Mumford (Honey \& Mumford, 2000), sharing D. Kolb's ideas, have described different learning styles and have worked out a test for identifying the preferred learning style. The researchers assert, that within the general cycle of empirical learning people start learning from the preferred style.

P. Honey and A. Mumford distinguish four learning styles: "activist", "reflector", "theorist" and "pragmatist".

Each type of learners has their own behavioral peculiarities, standards of educational process and requirements for other participants in this process. In the process of group teaching/learning, to which sol-fa course in a higher education institution belongs, students are taught and learn together and they learn one from the other.

The combination of different stages of the cycle gives four different styles/stages of learning according to P. Honey \& A. Mumford, which both intersect with Kolb's model and differ from it. According to P. Honey \& 
A. Mumford, learning styles are a product of combinations of stages of a learning cycle:

1. "Having the experience" (stage 1), and activist (style 1): sociable, seeks for difficult tasks and immediate experience, non-prejudicial, but soon gets tired from doing.

2. "Analyzing the experience" (stage 2) and reflecting type (style 2): collects data which reflects on and analyzes, postpones taking decisions, first listens before speaks.

3. "Making conclusions from the experience" (stage 3) and theorist (style 3): carefully thinks the questions over in a logical sequence, generalizes and combines different facts into a coherent theory, rationally objective, rejects subjectivity and thoughtlessness.

4. "Planning the subsequent steps" (stage 4) and pragmatist (style 4): explores and tries out new ideas, practical, likes to solve problems and quickly takes decisions, gets tired from long discussions.

P. Honey \& A. Mumford (Honey \& Mumford, 2000) assert that people, giving preference to one or the other style in a "pure form" occur quite seldom; as a rule, to a lesser or greater extent, elements of all styles are represented in each learner. Therefore, we can say that people give preference to different teaching/learning methods depending on the situation and level of their experience. However, the dominating tendencies determine both the peculiarities of a teaching/learning process and person's reaction to definite methods and teacher's attempts.

At developing David Kolb's idea, the Swedish researcher in the field of education, Klas Mellander (Mellander, 1993), represented the teaching/learning cycle in the following way:

- Motivation: psychological readiness and susceptibility;

- Information: facts and data are transformed into information;

- Processing: information is transformed into experience and understanding;

- Conclusions: the moment of "dawning upon" when the experience and understanding transform into knowledge;

- Employment: knowledge transforms into skills and approaches;

- Feedback: further reflection and improvement.

K. Mellander's teaching/learning scheme has been taken as the basis for determining the structure of sol-fa classes for pre-service music students oriented towards developing harmonic hearing.

\section{Research methods and sample}

Researcher Robert K. Yin (Yin, 1984/1994) defines the case-study research method as an empirical inquiry that investigates a contemporary phenomenon within its real-life context; when the boundaries between phenomenon and context are not clearly evident; and in which multiple sources of evidence are 
used (p. 23). R. Stake (Stake, 1995) points out that those are not the research methods that are important in a case-study, but rather the research object - a concrete case. The essence of the case-study lies in fact that here a real-life situation (fixed in some way) is to be comprehended; the situation which in its description not only reflects the problem, but also brings into focus certain experience and a complex of knowledge, which are to be acquired at solving the given problem. To achieve an educational effect the situation has to meet certain requirements. In it, there obligatory has to be a problem to solve, to describe and, if possible, try also to identify its cause. In the situation to be described (in this case - a concrete sol-fa class) the problem (development of harmonic hearing) must allow for several variants to solve it.

The types of learners (Honey \& Mumford, 2000) as well as the table of practical use of Kolb's model developed by G. Bazarova (Базарова, 2013) served as the basis for working out and defining the diagnostic questions for pre-service music teachers. The survey was conducted among a group of students from the Faculty of Music and Arts of Daugavpils University. The survey was aimed at exploring the results and determining the dominating learning style at sol-fa classes among the students studying in the "Music Teacher" program.

The results obtained from the conducted diagnostic survey were used for working out the technology of conducting sol-fa classes oriented towards developing harmonic hearing of students - pre-service music teachers. The developed questions (four for each learning style) were presented randomly. Students were supposed to select four questions which, in their opinion, were most important for them during the teaching/learning process and were directly related to the sol-fa subject.

The results of the diagnostics are received from real-life conditions where "the phenomenon of interest unfolds naturally" (Patton, 2002, P. 39).

14 junior course students of the speciality "Music Teacher" were involved in the diagnostic research. Two of them were males, 12 - females. Two participants worked as leaders of vocal ensembles, one - was involved in cultural work of regional self-government, two - were music teachers at secondary schools of general education. The different level of initial professional musical training of these students has to be mentioned here:

4 students - had graduated from a music school;

2 students - were graduates of secondary schools of general education which had offered in-depth music studies;

8 students - had diplomas of a special music school, besides, 5 of them had diplomas in two specialities - choir conducting and vocal, but two of them only in vocal, and one of them - only in choir conducting.

Therefore, from the very beginning it was clear that the results obtained from the diagnostic research might significantly differ. 


\section{Results of the study}

\section{A. Diagnosis of Students' Learning Style}

The results of the diagnosis of students' learning styles are as follows: out of the 14 1st and 2nd year students, 8 students gave priority to the learning style "activist", besides, only two of them were "pure activists", four - the combination of "activist - pragmatist", one - the combination of "activist theorist", one - "activist - reflector", and the remaining six students gave priority to the learning style - "pragmatist", out of which only two were "pure pragmatists", one - the combination of "pragmatist - theorist", two "pragmatist - activist", one - "pragmatist - reflector"; despite the equal distribution by types in a pair, the remaining three students were attributed to "pragmatists" so that the determination of the general learning style in the group could be formulated on the basis of one pair of the combination of learning styles.

Thus, the dominant style is "activist", while "pragmatist" comes the second in popularity. Let's try to combine these two learning styles ("activist" and "pragmatist") into one and characterize this bundle - personal experience practice:

- this is a group of learners who want to receive knowledge on the basis of their experience through method of experimenting and mistakes;

- explanation and demonstration of the teaching material are important for them;

- testing new knowledge in practice is significant;

- theorizing about and analysis of the given material remain in the background.

The preliminary data of diagnostic questions concerning students' learning style were the main source of information for the analysis of previous pedagogical experience and constructing a further pedagogical process. On the basis of these data the research question was formulated: Taking into account the priority learning styles, which methods are effective for the development of harmonic hearing of this specific group of learners?

B-Technology of Conducting Sol-Fa Classes

Using K. Mellander's learning scheme (on Kolb's theory) as the basis, the technology of conducting sol-fa classes was developed in this research; this technology was worked out by taking into account the learning style that was given the priority in a concrete group of students - pre-service teachers of music (the majority of them - activists).

The structure of the class consisted of the following components:

1. Participants' motivation (5 minutes from teaching/learning time);

2. Reinforcement and revising of the material covered (20 minutes);

3. Learning the new material (45 minutes);

4. Assessment (5 minutes); 
5. Debriefing (10 minutes).

This paper presents a sample of the material for one sol-fa class on the theme "Intervals. Augmented Fourth". This concrete class was devoted to the interval of the augmented fourth in major key on degrees I, II diminished, IV, VI, VI diminished. At acquiring these intervals, the succession of the previously developed author's model was used (Zavadska, 2012b):

- timbral characterization of the interval;

- spatial characterization;

- associative perception of sound nuance of the interval (method of a mutual comparison of intervals on different degrees in the major key);

- learning the tonal value of intervals.

Learning intervals presupposes a complex method. By analogy with work on the chord of the seventh, this method is based on working simultaneously with several elements. Intervals are not obligatory learnt strictly one after the other. The algorithm of conducting the class was worked out by taking into account the results of the diagnostic survey on students' learning styles in one course (6 people), the majority of whom were "activists" (4 people) and "pragmatists" (2 people).

Using the characteristics of students' learning styles as the basis, the structure of the class was developed and it made emphasis on learning the new material (See: Table 1).

Table 1

Algorithm of conducting a class

\begin{tabular}{|c|c|c|}
\hline $\mathrm{Nr}$. & Stage of a class & Time \\
\hline 1. & $\begin{array}{l}\text { Organizational part. Motivation- the beginning of a class: demonstration by a } \\
\text { lecturer of examples on the theme to be learnt, opportunities to use skills of } \\
\text { intoning intervals in practice. }\end{array}$ & 5 minutes \\
\hline 2. & $\begin{array}{l}\text { Checking how theoretical and practical music material has been learnt (including } \\
\text { also independent home assignment); practical examples for the analysis of intervals } \\
\text { ("auditory attack") }\end{array}$ & 20 minutes \\
\hline 3. & $\begin{array}{l}\text { a) Theoretical information on the structure and resolution of the augmented fourth: } \\
\text { timbral characterization of the interval; spatial characterization; method of mutual } \\
\text { comparison of intervals on different degrees in the major key. } \\
\text { b) intoning of intervals, vocal improvisation. } \\
\text { c) writing a music dictation (D. Shostakovich, fragment of a theme from the 1st part } \\
\text { of the Seventh Symphony). } \\
\text { d) Collective choral singing (sheet-singing of fragments of choral 3-4 voice } \\
\text { arrangements from Latvian folk and original music). } \\
\text { e) Composing of the 2nd and 3rd voice to a given folk song melody (home } \\
\text { assignment analysis) }\end{array}$ & 45 minutes \\
\hline 4. & Assessment. Summary given by a lecturer & 5 minutes \\
\hline 5. & Debriefing. The discussion with students on the results of the covered material & 10 minutes \\
\hline
\end{tabular}


This paper presents the problematic stages of work at sol-fa classes with a group of six 1st year students of Daugavpils University studying in the speciality "Music Teacher".

To develop students' skills of perceiving, analyzing and intoning intervals, musical-theoretical knowledge of their structure, place in the mode and their resolution is needed.

Theoretical information was simultaneously reinforced at both listening and analyzing interval sequences of instructive character:

$$
\begin{gathered}
\text { p. } 5 \text { - aug. } 4 \text { - p.5 - aug. } 4 \text { - p.5 - intervals } \\
\text { I I I I II I - degrees }
\end{gathered}
$$

Fragments from instrumental and choral compositions by various composers were also used (F. Chopin's Balad $g$ moll, S. Prokofiev's Gavotte from Classical Symphony, A. Jurjāns' Pūt, vējini (Latvian folk song), J. Vītols' Gaismas pils); and on analyzing them by ear several methods were applied: method of comparison (tonal values), of timbral-sound analogies with other intervals (e.g., perfect fourth, perfect fifth), of associative perception of intervals (according to M. Karaseva's (Karaseva, 2009) scale).

When intervals were intoned, besides individual intoning of independently composed and prepared interval sequences (home assignment), choral vocal improvisation was done. In it, all students participated: against the background of the interval to be intoned - augmented fourth and its resolution (different variants - on degrees I, IV, VI, II, VI, IV), one or two students improvised a monophonic melody.

For a music dictation, a melody was given - a fragment of a main part from the first part of the Seventh Symphony by D. Shostakovich, whose one intonation is movement along sounds of the interval of the augmented fourth on degree I Do major and its resolution into the perfect fifth on degree I. First, the original version of this composition (performed by the symphonic orchestra) on CD was given for students to listen to. Then, after the melodic line, structure, peculiarities of mode and rhythm, difficult intonation problems had been analyzed together with students, the fragment of D. Shostakovich's theme was performed on the piano in monophonic rendering.

For a collective choral music making fragments of choral compositions by Latvian composers were offered: E. Dārziņš - Lauztās priedes, E. Ešenvalds - Tu nekad neesi viens.

For composing the 2nd and the 3rd voice to the given melody, students were offered a theme from a folk song Kas tie tādi, kas dziedāja (home assignment). After the analysis of the melody, structure of the theme, peculiarities pertaining to harmony (possible interval combinations), and peculiarities of choral twoand three-voice texture, the audio recording of the piano arrangement of this folk song by the Latvian composer Jēkabs Graubinš was given as an example.

A serious learning/teaching problem in a case-study is the assessment of the participants of the discussion. At checking and assessing the level of students' 
knowledge, the lecturer takes into account the following didactic principles of education:

- objectivity - creating conditions in which learners' knowledge could be maximally revealed, setting common requirements for them, fair attitude to everybody;

- validity of grades - argumentation of them;

- regularity - most important psychological factor, which organizes and accustoms students to discipline.

During a class, the level of students' knowledge was assessed according to work forms:

- analysis of interval sequences by ear;

- writing a music dictation;

- singing of three-voice music sample in trio (independent home assignment).

The assessment was done according to a 10-grade scale. The results of the assessment of the level of students' knowledge by work of the development of harmonic hearing of six (out of 14) students obtained from the research are as follows:

Table 2

Results of the assessment of the level of students' knowledge by work forms

\begin{tabular}{|l|l|l|l|l|}
\hline \multicolumn{1}{|c|}{ Students } & \multicolumn{1}{|c|}{$\begin{array}{c}\text { Interval } \\
\text { sequences }\end{array}$} & $\begin{array}{c}\text { Music } \\
\text { dictation }\end{array}$ & $\begin{array}{c}\text { Ensemble } \\
\text { (trio) }\end{array}$ & Total \\
\hline AC & 9 & 9 & 8 & 26 \\
\hline AG & 7 & 6 & 8 & 21 \\
\hline AK & 8 & 7 & 7 & 22 \\
\hline VV & 5 & 4 & 8 & 17 \\
\hline VK & 8 & 7 & 7 & 22 \\
\hline GS & 9 & 9 & 7 & 25 \\
\hline
\end{tabular}

The comparison of the total number of grades by work forms indicates that the analysis of interval sequences by ear has yielded the highest results, while writing a music dictation appeared to be the most difficult task. Before writing a dictation students, assisted by a lecture, analyzed meter-rhythmic intonation peculiarities of D. Shostakovich's theme. On the whole, the results were lower, to some extent, than the results of the analysis by ear, which can be attributed to the complexity of this work form - writing down a melody by ear.

If the obtained results are analyzed by total grades of individual participants, we see that students with secondary special education (conducting and vocal) have received the highest grades. Students who have been trained at music school's choir class received the lowest grades. Students' high results are to be attributed to their previous excellent musical training and regularity of classes. And on the other hand, the student's (VV) low result in the analysis of interval sequences by ear and writing a music dictation can be explained by the low level of theoretical 
knowledge and practical auditory skills, due to the unsystematic attendance of classes (quite a great number of classes missed).

B.Nezvanov and A. Laschenkova (Nezvanov \& Laschenkova, 1967) maintain that singing in ensemble is an important tool of developing harmonic hearing. Students demonstrated good results in singing three-voice musical sample in trio (independent home assignment). A sufficiently high level of results in this work form can be attributed to the traditions of Latvian culture. Choral singing, being a variety of collective music making, is an integral part of Latvian musical culture in general, and all students are members of some choir (Zavadska, 2013). Debriefing during the classes is aimed at analyzing the experience students have obtained at fulfilling various practical tasks. Students get involved in the discussion of real-life situations and therefore their position is active. The choice of the best solution within the context of the set problem is made through the analysis of the material covered during the class.

The lecturer answers questions that arise during the analysis. The discussion and exchange of opinions among all the participants occur: the lecturer and the students. The lecturer controls the situation and acts in the role of a coordinator and leader of the discussion.

M. Ments (Ments, 1998) maintains that at a debriefing stage it is essential for the learners to get abstracted from the content of the situations that have arisen, and to make the analysis of what is going on.

One of the discussion questions was: Which of the methods used by the lecturer, in learners' opinion, are the most effective for acquiring skills of intoning intervals and aural analysis?

When assisting the students to find scientific substantiations for defining methods, the lecturer characterized various aspects of teaching methods, made comments and remarks and asked students to offer their opinion concerning the given question.

In the result of the discussion, the following effective teaching methods were determined (according to the priorities of learning styles):

- method of demonstrating the taught material by a lecturer and simultaneous explaining how a specific interval is to be correctly intoned;

- method of a contrastive comparison (one, two or more intonations of the augmented fourth are singled out of the offered motif, and are analyzed and intoned as sequences);

- method of sound analogy (signal of the first aid);

- method of visual association (effect of an opening flower bud at resolving augm. 4 on degrees IV and VI);

- method of choral vocal improvisation models certain characteristics of the interval and fulfills the function of reinforcing peculiarities of the interval to be learnt in a creative activity. 
Thus, it is the form of discussion in learners' interaction that shapes and develops skills of ability to listen, teaches to substantiate one's own position. The lecturer, in turn, may check on whether the learners have acquired the material and whether all of them have correctly understood the problem discussed during the class.

\section{Conclusions}

On the basis of D. Kolb's conception (D. Kolb, 1984), learners' types defined by P. Honey \& A. Mumford (Honey \& Mumford, 2000) and the table for practical use of D. Kolb's model developed by G. Bazarova (Базарова, 2013), diagnostic questions were worked out and determined for pre-service teachers of music. This allowed determining the priorities given to learning styles in a concrete group of students.

1. On the basis of K. Mellander's (Mellander, 1993) scheme of teaching, the technology of conducting a sol-fa class oriented towards developing harmonic hearing of pre-service music teachers was worked out, the example of the developed material on the theme "Intervals. Augmented Fourth" was presented. When learning these intervals, the sequence of previously developed author's model was used:

- timbral characterization of the interval ;

- spatial characterization;

- associative perception of sound nuances of the interval (method of mutual comparison of intervals on different degrees of the major key);

- learning the tonal value of the interval (Zavadska, 2012b).

2. The conducted research yielded the highest results in the indicators related to students' practical music making - polyphonic singing. This can be attributed to the strong tradition of choral singing in Latvian culture. Good results in the analysis by ear are indicative of a correct choice of methodology of presenting the theoretical and practical material which affects the effectiveness of acquiring knowledge by students.

3. The collective discussion resulted in determining effective teaching/learning methods for developing harmonic hearing:

- method of demonstration;

- method of contrastive comparison;

- method of sound analogy;

- method of visual association;

- method of choral vocal improvisation.

\section{References}

1. Honey, P. \& Mumford, A. (2000). The Learning Styles Helper's Guide. Maidenhead: Peter Honey Publications Ltd. 
2. Karaseva, M. (2009). Sol-Fa - Psychotechnique of the Development of Musical Hearing [Сольфеджио - психотехника развития музыкального слуха] Moscow: Kompozitor (in Russian).

3. Kazkayasi, M., Yetiser, S. \& Ozcelik, S. (2006). Effect of musical training on musical perception and hearing sensitivity: Conventional and high frequency audiometric comparison. The Journal of Otolaryngology, 35 (5), 343-348.

4. Klarin, M. (1989). Pedagogical Technology in the Educational Process [Педагогическая технология в учебном процессе.] Moskow: Znanie (In Russian).

5. Kolb, D.A. (1984). Experiential Learning: Experience as the source of learning and development. Prentice-Hall, Inc., Englewood Cliffs, N.J.

6. Mellander, K. (1993). The Power of Learning: Fostering employee growth. Publisher: McGraw-Hill Trade. ISBN-10: 1556238932. Retrieved [21.03.2013] from http://www.goodreads.com/book/show/4630891-the-power-of-learning

7. Ments, M. (1998). Rollenspiel: effektiv. Ein Leitfaden für Lehrer, Erzieher, Ausbilder und Gruppenleiter. München: R. Oldenbourg Verlag (EGS-Texte). ISBN 3-486-02699-2

8. Nezvanov, B. \& Laschenkova. A. (1967). A Reader on Aural Harmonic Analysis [Хрестоматия по слуховому гармоническому анализу]. Leningrad: Muzika (In Russian).

9. Patton, M. Q. (2002). Qualitative evaluation and Research Methods (3rd ed.). Thousand Oaks, CA: Sage Publications, Inc.

10. Petrushin, V. (1997). Psychology of Music [Музыкальная психология] Moscow: Vlados (in Russian).

11. Rogers, Carl. (1969). Freedom to Learn: A View of what education might become. (1st ed.) Columbus, Ohio: Charles Merill.

12. Sloboda, J. A. (1988). The Musical Mind: The cognitive psychology of music. Oxford: Oxford University Press.

13. Soy, S. K. (1997). The case study as a research method. Unpublished paper, University of Texas at Austin. Retrieved [21.03.2013] from http://www.gslis.utexas.edu/ ssoy/usesusers/1391d1b.htm

14. Stake, R. E. (1995). The Art of Case Study Research. Thousand Oaks, CA: Sage.

15. Teplov, B. (1947). Psychology of Music and Musical Abilities [Психология музыки и музыкальных способностей]. Moscow, Leningrad: Izdatelstvo Pedagogicheskih Nauk (in Russian).

16. Yin, R. (1984/1994). Case Study Research: Design and methods. Thousand Oaks, London, New Delhi: Sage.

17. Zavadska, G. (2011a). Theoretical basis of professional musical hearing.//Arts and Skillssource of Well-being. Third International Journal of Intercultural Arts Education. Helsinki, 181-191. ISSN 1799-2508

18. Zavadska, G. (2011b). The Structure of Music Teacher's Professional Musical Hearing. //The Changing Face of Music and Art Education: Yesterday, Today, Tomorrow. Interdisciplinary Journal for Music and Art Pedagogy. Volume 3 -Tallinn, 93-108. ISSN 2228-0715

19. Zavadska, G. (2012a). Theoretical basis of harmonic hearing. A. Šļahova (Ed.) Scientific Articles of $7^{\text {th }}$ International Conference "Person. Color. Nature. Music". Daugavpils: Daugavpils University Academic Press "Saule", 275-285.

20. Zavadska, G. (2012b). Model for developing student teacher's harmonious hearing introduction. J. Davidova (Ed.) Problems in Music Pedagogy. Volume 10, Daugavpils: Daugavpils University Academic Press "Saule", 59-71.

21. Zavadska, G. (2013). The analysis of results obtained at diagnosing the development of prospective music teachers' harmonic hearing. The Changing Face of Music and Art 
Proceeding of the International Scientifical Conference May $23^{\text {th }}-24^{\text {th }}, 2014$ Volume II

Education: Inspiration and improvisation. Interdisciplinary Journal for Music and Art Pedagogy. Volume 5/1 -Tallinn, 129-149. ISSN 2228-0715

22. Базарова, Г. Менеджер по персоналу . [Staff Manger] Retrieved [22.10.2013], from http://www.hr-portal.ru/article/osobennosti-obucheniya-vzroslyh 